\title{
THE ART AUDIENCE AS A CULTURAL PHENOMENON
}

\author{
${ }^{1}$ A. Makulbekov, ${ }^{2}$ T. Dronzina
}

\section{ABSTRACT}

Despite some theories based on the concept of "arts for art" and denying the connection with the public, in trend art cannot exist in Russia without the public. Only through the public art transmit an artistic message and realize its social functions. Relations with the public especially determine the development of art, the conditions for the existence of its institutions. Therefore, they always remain among the main subjects in the studies of the social functioning of art, bringing to the foreground one or another aspects of interaction. Modern civilizational trends are globalization, urbanization and the information technology revolution - which contributed to the rapid development of mass communication media, opened up unprecedented opportunities for introducing wider masses to culture and art, turned art into an element of everyday life of a mass person.

Keywords: Audience, Public, Communication, Theater, Cinema, Television.
${ }^{1}$ L.N. Gumilyov Eurasian

National University,

Nur-Sultan, Kazakhstan

${ }^{2}$ Sofia University, «St. Kliment Ohridski» at the University of Sofia, Bulgaria

Corresponding Author:

A.T.Makulbekov,

aidossozak@mail.ru

Reference to this article:

Makulbekov A., Dronzina T., Akhmedova Z. Upbringing and Education as Factors of Human Capital Development

// Adam alemi. - 2021. - No. 3 (89). - P. 16-23.

\section{Аудитория искусств как культурный феномен}

\begin{abstract}
Аннотация. Несмотря на отдельные теории, опирающиеся на концепцию «искусства для искусства» и отрицающие связь с публикой, в тенденции искусство без публики существовать не может. Только через публику искусство транслирует художественное сообщение и реализует свои социальные функции. Отношения с публикой в большой мере определяют развитие искусства, условия существования его институций. А потому они всегда остаются в числе основных сюжетов в исследованиях социального функционирования искусства, выдвигая на первый план то одни, то другие аспекты взаимодействия. Современные цивилизационные тренды - глобализация, урбанизация и информационно-технологическая революция - способствовавшие бурному развитию средств массовой коммуникации, открыли невиданные ранее возможности приобщения к культуре и искусству все более широких масс, превратили искусство в элемент повседневного быта массового человека.
\end{abstract}

Ключевые слова: аудитория, публика, коммуникация, театр, кино, телевидение.

\section{Өнер аудиториясы мәдени феномен ретінде}

Аннотация. "Өнер тек өнер үшін" тұжырымдамасы өнер аудиториясының көрерменмен байланысын теріске шығаратын теорияларға қарамастан, өзінің үрдісінде өнер аудиториясыз тіршілік ете алмайды. Тек аудитория арқылы ғана өнер көркемдік хабарламасын таратып, өзінің әлеуметтік функцияларын іске асырады. Аудитория қарым-қатынас арқылы өнердің дамуы мен оның онтологиялық шарттарын анықтауға мүмкіндік береді. Өзара әрекеттесу аспектілері арқылы өнердің әлеуметтік қызмет етуін қамтамасыз етеді. Бұл тақырып бүгінгі 
модернизациялану кезеңінде өте өзекті екені сөзсіз. Бұқаралық қатынас құралдарының қарқынды дамуына болысатын бұрын-соңды болып көрмеген жаһандану, ақпараттықтехнологиясы сияқты заманауи өркениетті беталыстар байқалады. Соңғы жылдары кең белең алып жатқан бұқаралық ақпараттар арқылы мәдениет пен өнерге ықпал ету мен оларды қалыптастыру мүмкіншіліктері пайда болды және өнерді адамның күнделікті тұрмысының элементіне айналдырды.

Түйін сөздер: аудитория, жұртшылық, байланыс, театр, кино, теледидар.

\section{Introduction}

The accompanying social processes, the revision of value orientations and norms, the evolution of the system of artistic needs and demand for cultural goods have fundamentally transformed the conditions of cultural life and the institutional environment, breaking the age-old forms of existence of traditional forms of art. The cultural activity of a person has long been not limited to attending performances, concerts, art expositions, that is, "live" contacts of a person with art. But along with the positive effects of expanding the availability of art, the ongoing processes "reduce the possibilities of expanded spiritual reproduction of the individual and create real risks: reducing the already rather modest leisure role of art, further stratification of art into elite and mass, replacing a person's live communication with art with household consumption of his digital virtual images supplied via the Internet and the media, the final transformation of art into an industry" [1].

The influence of global trends on artistic culture is being refracted and strengthened in a peculiar way in the conditions of the current stage of socio-economic and cultural development of our country. The trend of commercialization of art, the loss of freedom and the subordination of artists to the requirements of the market, noted by P. Sorokin in the middle of the XX century, became especially relevant [2]. The adoption of the market paradigm and the related revision of the principles of state cultural policy forces cultural and art institutions to increasingly rely on their own resources and capabilities, focusing their activities on meeting the needs of the end consumer - the viewer, listener, visitor.

\section{Cultural Interests and Value Orientations of Society}

The current situation of the existence of art in our country is characterized by a significant expansion of the supply and the presence of serious market competition between producers of cultural goods in the struggle for a potential consumer against the background of a significant expansion of leisure opportunities of the population. In the conditions of ambiguity of consumer choice criteria, the success and viability of works of art, their market prospects are determined not so much by their artistic and aesthetic merits, as by purposefully formed mass demand, which dictates the conditions and rules of the game to artists and distributors of artistic goods, determining, ultimately, the trends of artistic life. The awareness of the exceptional importance of the processes taking place in the sphere of culture stimulated the development of applied research of artistic culture, which is faced with the task not of studying individual facts, but of comprehending the mass laws of the evolution of cultural needs, as well as the behavior of people and society in relation to artistic culture. At the same time, in the modern actualization of the issues of relations between producers and consumers of artistic goods, the problem of the existence of communication barriers between art and its audience clearly appears as a result of insufficient knowledge of many essential characteristics of the art audience, lack of understanding of the origins and patterns of its cultural and economic behavior. 
Theoretical understanding of the challenges of the time and the development of scientific concepts is becoming extremely relevant in solving many practical problems of the social functioning of art.

\section{Research Methods}

Scientific research that had a significant impact on the evolution of organizations understanding of the art of their audience. Scientific research that had a significant impact on the evolution of organizations understanding of the art of their audience. The research results are used to improve the artistic offer, develop marketing programs, and help expand and diversify ideas about who visits and why visits art organizations. Thus, a serious study of the audience of consumers, the art market with a real reliance on empirical facts today is not only an urgent scientific task, but also a necessary condition for the successful functioning of any organization of culture and art.

The study of the audience has a rich history, and the first experience of this kind that has come to us is study of visitors in the Liverpool Museum, conducted in 1884 [3]. This study marked the beginning of regular efforts to categorize the public. However, a deep philosophical understanding of the problems of art's relations with society began much later. At about the same time, the theoretical sociology of theater (J. Duvignot) and music (T. Adorno) took shape as relatively independent disciplines. However, in their development, the theoretical and empirical branches of the sociology of art were not identical, which gave rise to a discourse about the role of theory and empiricism in the study of the processes of social functioning of art. So, t. Adorno, in his philosophical reflections, insisted on the fundamental non-identity of the art of social reality. And the German sociologist A. Silbermann, arguing with T. Adorno on this issue, called for the formation of a science about art as a social phenomenon based on sociological generalizations of empirical data. At the same time, the most important methodological principle of a comprehensive study of cultural life as the interaction of artists, works of art and the public was postulated[4]. The intensification of empirical research of the art audience in the West in the second half of the $X X$ century was largely due to the fact that they were included in the mandatory agenda of American and European cultural institutions "due to the need to provide quantitative and qualitative indicators of their activities to state structures, sponsors and donors"[5]. It was largely due to the fact that they were included in the mandatory agenda of American and European cultural institutions "due to the need to provide quantitative and qualitative indicators of their activities to state structures, sponsors and donors"[5]. Subsequently, public research organizations were established in Canada (1991), the USA (1992), Australia (1995), Great Britain (1998), and a number of other European countries, and the study of social problems of the functioning of art organizations was put on a permanent basis.

In recent decades, research on the audience of certain types of art in the West has been very active. The results of these studies are published in regular reviews or on special network portals, as well as in the form of author's publications of the results of specific empirical studies. Among the modern foreign scientists who are actively engaged in research of this kind, we can name the following: S. Askegaard, L.D. Dierking, J. Dodd, J.H. Falk, D. Fleming, V. Golding, T.K. Hamann, M.K. Hogg, J.T. Jensen, C. Jones, B. Kolb, N. Lebrecht, L. Levy-Garboua, I.B. Lundgaard, B. Lynch, M. Meleddu, C. Montmarquette, J. FrietoRodriguez, R. Sandell, C. Scott, B.A. Seaman, J.M. Schuster, M. Solomon, etc.

At first, the interest in the public did not pretend to be scientific and did not set the task of identifying the laws of the social functioning of art. But as the audience of art grew, its importance for the development of art was increasingly realized not only as a perceiving side and an object of influence, but also as an active participant in the artistic process, able to 
influence artists and the development of art. The interest in the audience from artists and art theorists naturally grew and acquired an increasingly special character.

"Before the public was still small and fairly homogeneous in class, cultural and psychological terms, but after at the turn of the XIX-XX centuries the problem of the public becomes really relevant"[6]. With the awareness of the role of the public in the artistic process came the understanding of the importance of its systematic study. In that time "experiments began to study the relationship of the public with fiction and theater at the level that can be legitimately considered as a more or less scientific view of solving the problem" [7].

The interest to the public and the realization that the history of art is not limited to the history of artistic works, and in the study of the problems of the social functioning of art, its relations with the viewer, listener, visitor have become the dominant plot.

The audience of the theater tools for studying the audience of art [9]. Owing to these works, the history and results achieved in the study of the public of performing arts and art museums are recreated in sufficient detail.

Unlike many Western countries, where the study of the art audience was stimulated by constant institutional pressure, in our country the interest in the problem was not so applicable nature. It was connected both with the improvement of the activities of cultural institutions and attempts to scientifically substantiate the state cultural policy, and with the theoretical understanding of the problems of human relations with art.

In recent decades, the study of the art audience based on empirical research in our country has been conducted in two directions.

1. Research on sociological surveys of the population gives the most holistic view of society, the public and art. The study of the opinions and behavior of the population in relation to art allows us to assess the role of art in people's lives, to identify the structure and dynamics of cultural interests and preferences, to recreate a picture of the cultural life of a country or a particular region. Studies of this kind are an indispensable tool in solving general problems of the social functioning of art, determining the priorities of cultural policy. Comprehensive studies of the social functioning of art based on population surveys have great epistemological and prognostic potential, but their spread is hindered by the extreme complexity and cost of conducting.

2. Specific sociological studies of the art audience based on surveys of visitors to cultural and art institutions have a lower level of generalization, but they provide researchers with more detailed and reliable information about the actual audience - visitors, viewers, listeners. Allowing to solve both some theoretical and practical institutional problems, such studies become a condition for the normal functioning of cultural and art institutions and an effective tool for improving their work. In the research directions developed by them, the theoretical aspects of the social functioning of theatrical art and the methodological problems of conceptualization of the theater audience were combined with practical tasks of an institutional nature.

Considering cinematograph as a social institution, these scientists investigate the problems of the social role of cinematograph, the creation, distribution and perception of films. Attempts are also being made to comprehend the content of the screen world, its impact on the public. The focus of attention is not only on the problems of conceptualization of the audience of moviegoers, their film preferences and statistics of film attendance, but also on philosophical issues of the cinematic life of society.

\section{The Audience as an Object of Mass Information}

The article is devoted to the key element of the media system, which from the very 
beginning of the development of the system was considered as an object of influence of the mass media. This position has long been introduced into the public consciousness by the ruling elites, who manipulated the masses, imposing favorable images and stereotypes on them. Therefore, the works of Western philosophers and psychologists, who considered the masses as a primitive crowd, "a lot of people without special merits", whose companions are immorality and stupidity, contributed in many ways. If we analyze the numerous definitions of the term "mass information", then almost all the formulations can be reduced to a generalized concept of mass information as social information distributed by technical means to an unlimited audience and causing mass interest. That is, the media is the source of information, and their audience is the receiver of this information, or, in other words, the object of the information subject's activity. And the flow of information is one-sided from the media to the audience. The place and role of the audience in the traditional media system, the concepts of "audience", "mass", "mass information"are considered. At the turn of the XIX-XX centuries, the social philosopher G. Tard saw both similarities and differences between the three cases of the mass - the crowd, the public, the audience - the types of mass are historically conditioned, appear due to changes in the nature and conditions of interaction in society, the development of communication technology leads to the fact that "instead of crowds gathered in the same closed space, at the same time, from now on we are dealing with scattered crowds, those with the public. Mass in the context of media research means primarily an audience consisting of consumers of cultural products, which is relatively large and not differentiated by place of residence and social class. To be mass means to be anonymous in relation to the communicator and to each other". The defining characteristic for the mass media should be the need of the masses for it, and this consists in its general significance (information carries information that to some extent concerns everyone) and accessibility (it is distributed through open channels and is objectified either in natural language or in such artificial languages that the masses own). As a result, it turns out to be 8 able to form a spiritual bridge between representatives of different social communities - with different life experience, different specialization in work, with different group (including class) positions. An audience can be defined as a stable set of people that arises on the basis of the commonality of their information needs, interests (arising from their social affiliation), as well as forms, methods, channels for meeting these needs, the deeper and better a media outlet responds to people's requests, the wider and more stable its audience is. One of the bases for the media typology is the characteristics of the audience. They include socio-demographic, socio-professional, socio-cultural parameters that serve as the basis for the formation of target media audiences. The main difference between the mass audience and the target audience is passivity in the search and perception of information. The social expectations of the mass consumer of information dictate to its producer what exactly, through what channels, in what forms should be presented to the audience by the media operating in the conditions of mass culture, in relation to the audience, they choose an expansion strategy. It reflects the general trend towards unification inherent in the mass press and television. The condition for unification for the audience is the freedom of access to information. In market conditions, the media audience has become regarded as a key commodity produced by the media for further resale to advertisers. The mass consumer of radio and television information "pays" with his time, which, in turn, is paid by the advertiser. The editorial 
offices of radio and television set advertising $j$ prices depending on the rating of programs, those on the volume of the audience at certain intervals of broadcasting time. Lenin developed a new model and theory of the socialist press In his writings, which was transformed from an organ of reporting political news into an organ of economic education of the masses. In the first place, it put forward the issues of labor, the development of a conscious attitude of the masses to it. The main topic was the organization of competition on socialist principles, ensuring transparency and comparability of the results of the work of labor collectives, the possibility of practical repetition of the experience of the best of them. The main principles and proclaims are party membership, nationality and mass character of the press. The main functions are agitation, propaganda and organization of the masses. Mass information was introduced into the strict course of the party-state management of the population. During the years of Stalin's rule and Under Stalin, the media turned into an effective tool for ideological management of society, a "driving belt" between the party and the masses, their role was also great in creating a cult of the leader's personality, mythologizing the life of the country of workers and peasants. A simplified perception of social phenomena, historical figures and events prevailed on the pages of newspapers and on the air. The monopoly on the truth in the hands of the country's leadership made it possible to make an arbitrary selection of these historical figures, to conceal or exaggerate the significance of their activities. In the following decades, the Soviet media continued to serve the interests of the bureaucratic apparatus, which did not trust the masses, believed that they should be constantly educated, nationalized, and effectively managed. This has further strengthened the sociological interpretation of the mass media. "The mass media should include not only those with which journalists, officials, specialists speak, but also those that write to the editorial office, people tell journalists. The most accurate definition seems to be that mass information is a type of social information that the mass operates at any stage of its existence (production, distribution, consumption)". The participation of the population in the production of mass information has become one of the conditions for the effectiveness of journalism. According to Mr. Schiller, the involvement of many people in information activities on their own initiative ultimately represents the most reliable protection of society from control over information and manipulation of consciousness. When the power was in the hands of the liberals, and they turned from "socialism with a human face" to the market, the discussion with the media audience of the ways of developing a nationwide state lost its relevance, the path was chosen. Therefore, live discussions on political and economic problems have become limited to a narrow circle of specialists who support the new course. The dialogization of the media and the people was smoothly transferred to the circle of leisure interests, various entertainment programs and talk shows. The restoration of capitalist relations in society has led to the growth of general political and information-commercial media of the Western type, both in content and in form. The audience was again considered as an object of information and propaganda influence, as a potential buyer of an information product. Media owners were primarily interested in the rating of publications, which, first of all, is appreciated by advertisers, on whose finances the success of the current media is based. Politicians have turned the audience - the electorate into an object of manipulative electoral technologies. During the years of reforms, the media owners managed to wean the audience from active participation in the life of society through the mass media. 


\section{Conclusion}

A new problem has also been reflected in the social studies of the art audience of recent decades - many empirical results are still waiting for their theoretical interpretation. It must be admitted that despite the obvious success in conceptualizing the audience, many important aspects of cultural aspects have not yet been sufficiently studied.

For example, the role of motivations and intellectual and cultural resources of the individual, the nature of individual preferences, evaluation of the results of visits and other diverse forms of human relations with art. The study of the motivational sphere and other manifestations of the inner world of a person as a source of subjective attitude to art cannot be standardized, and this determines the relative freedom of researchers both in setting tasks and in choosing ways to solve them.

Studies of the last decades accurately reproduce the picture of the artistic life of the country, the attitude of the population to art and the socio-cultural portrait of the audience. Today we have the opportunity to supplement this picture with information about the origins of cultural activity, the determinants and patterns of a person's introduction to art and his consumer behavior. At the same time, we are interested not only in general issues of cultural consumption, but also in the special things that characterize the real audience of different types of art: theatrical, musical, visual.

The aim of the research was a theoretical understanding and generalization from the standpoint of modern science of the laws and current trends in human relations with art, empirically recorded in the course of social dimensions. And you have found the need for:

1. Critical analysis and generalization of the world experience of studying the art audience. of $\begin{gathered}\text { Search and substantiation } \\ \text { methodological approaches }\end{gathered}$

adequate to modern challenges to the conceptualization of the art audience, the principles of the typology of the public and the segmentation of the art market.

3. Development of a system of meters and indicators that provides the possibility of operationalization of concepts and measurement of meaningful characteristics of a person, its motivational features and behavioral manifestations.

4. Identification of latent connections and trends in the cultural and leisure behavior of the population, its attitude to art, determination of the main leisure strategies.

5. Determination of trends in the evolution of the role of art in the life of a modern person, its connection with the socio-economic transformations of society.

6. Comprehensive characteristics of the art audience, in addition to its traditional socio-demographic descriptions.

7. Development of approaches to the content typology of the art audience, identification of the main trends and patterns in the consumer behavior of its various segments.

8. Clarification of traditional ideas about the role of socio-demographic characteristics and identification of real drivers of cultural activity.

9. Measurement of the relationship of cultural activity with intellectual and cultural resources of the individual and the characteristics of motivation.

10. Search for patterns of introducing a person to art and features of audience reproduction.

11. Identification of the most significant factors that have a statistically significant impact on the attendance of cultural and art institutions.

The question of the origins, determinants and patterns of cultural activity becomes the leitmotif of the entire study. Until now, this question has rarely been raised in the course of empirical research in a strictly 
evidential form. The reason is primarily that such problems cannot be solved by traditional descriptive methods and require more accurate and reliable analytical tools.

The subject of the research is the changing system of artistic needs and the role of art in people's lives, current trends in human relations with art, as well as their determinants - a complex of sociocultural and psychological characteristics of a person, his individual preferences and motivations that influence cultural activity.

\section{References}

1 Ushkarev A. A. Dynamics of artistic needs; causes and consequences. Culture and Art, 2018. p. 22.

2 Sorokin P.A. Man. Civilization. Society. General ed., comp. and preface by A. 10. Soyumonov: Trans. from English M.: Politizdat, 1992. 543 p.

3 Bitgood, S. Attention and Value: The Keys to Understanding Museum Visitors, Left Coast Press, Walnut Creek, Califomia, paperbaek, 2013,213 pp.

4 Silbermann A. Einpirischc Kunstsoziologie Eine Einfehrang mit kommentierter Bibliographie. Stuttgart, 1973. $238 \mathrm{~s}$.

5 Maksimova A., Ryumina C., Lobanova L.
Guide to the research of museum visitors. Moscow: Polytechnic Museum, 2016. p. 8.

6 Khrenov I. A. The public in the history of culture. The phenomenon of the public in the perspective of mass psychology. M., 2007. pp. 340-352.

7 Focht-Babushkii Yu. U. Art in human life. Specifically, sociological studies of art in Russia at the end of the XIX-first decades of the XX century. History and Methodology. St. Petersburg, 2016. p. 187.

8 Theater as a sociological phenomenon. Ed. II. L. Khrenov. St. Petersburg: Lleteya, 2009

9 Egorova M. N. Theatrical audience. The evolution of the questionnaire method. Moscow: GIl, 2010. 162 p.

\section{Transliteration}

1 Baader V., Done E., Vrenderfer M. Predmet i naznachenie filosofii istorii [The subject and purpose of the philosophy of history]. M.: Kolos, 1986. - 148 s. (in Russ)

2 Zavarzin G.A. Gumanitarnoe znanie i moral'nye razmyshlenija [Humanitarian knowledge and moral reflections]// Izv. RAN, Ser. filosofija. - 1996. - N 6. - S. 24-34. (in Russ)

3 Hamidov A.A. Mirovozrenie i filosofija [World view and philosophy] // Adam alemi. 2020. - N 3. - S. 19-31. (in Russ)

\section{INFORMATION ABOUT AUTHORS}

Makulbekov Aidos Tolebekuly

Dronzina Tatyana Aleksandrovna

Мақұлбековв Айдос Төлебекұлы

Дронзина Татьяна Александровна

Макулбеков Айдос Толебекуль

Дронзина Татьяна Александровна
PhD, L.N. Gumilyov Eurasian National University, NurSultan, Kazakhstan

Professor, Doctor of Politology, professor, Sofia University, «St. Kliment Ohridski» at the University of Sofia, Bulgaria

$\mathrm{PhD}$ докторант, Л.Н.Гумилев атындағы Еуразия ұлттық университеті, Нұр-Сұлтан, Қазақстан

профессор, саясат ғылымдарының докторы, Әулие Климент Охридский атындағы София мемлекеттік университеті, София, Болгария

$\mathrm{PhD}$ докторант, Евразийский национальный университет имени Л.Н. Гумилева, Нур-Султан, Казахстан

профессор, доктор политических наук, Софийский государственный университет имени Святого Охридского, София, Болгария 